Article

\title{
Temporal, Plant Part, and Interpopulation Variability of Secondary Metabolites and Antioxidant Activity of Inula helenium L.
}

\author{
Nenad Zlatić ${ }^{\mathbb{D}}$, Dragana Jakovljević * and Milan Stanković(i) \\ Department of Biology and Ecology, Faculty of Science, University of Kragujevac, 34000 Kragujevac, Serbia; \\ nzlatic@gmx.com (N.Z.); mstankovic@kg.ac.rs (M.S.) \\ * Correspondence: draganaj@kg.ac.rs; Tel.: +381-34-336-223
}

Received: 3 June 2019; Accepted: 15 June 2019; Published: 17 June 2019

\begin{abstract}
Variations in abiotic environmental factors have significant effects on quantity and quality of secondary metabolites, which is particularly important for plant species that possess biologically active compounds. The purpose of this study is determination of the total phenolic content, flavonoid concentration, and antioxidant activity of the different parts of Inula helenium L. (Asteraceae) sampled from different populations and in different time periods. The amounts obtained for the total phenolics varied from 16.73 to $89.85 \mathrm{mg}$ of gallic acid (GA)/g. The concentration of flavonoids ranged from 9.32 to $376.22 \mathrm{mg}$ of rutin $(\mathrm{Ru}) / \mathrm{g}$. The $\mathrm{IC}_{50}$ values of antioxidant activity determined using the 1,1-diphenyl-2-picrylhydrazyl (DPPH) free radical method varied from 161.60 to $1563.02 \mu \mathrm{g} / \mathrm{ml}$. The inflorescence and roots possessed high concentration of phenolic compounds and significant antioxidant activity, while leaves contained the highest concentration of flavonoids. Additionally, the quantity of the phenolics, as well as antioxidant activity, significantly varied among the different populations due to different impacts of environmental factors. This research showed that I. helenium represents an abundant source of bioactive substances, and that the quantity of these compounds greatly differs among the different populations as well as in the same populations regarding the different time periods as well as plant parts.
\end{abstract}

Keywords: practical importance; antioxidant activity; phenolic compounds; quantitative analysis; spatio-temporal variability; environmental factors

\section{Introduction}

As a part of adaptive strategies to the variability of environmental factors, plant secondary metabolites have major roles in the adaptation of plants to unfavorable conditions [1]. Secondary metabolites, therefore, participate in the process of the adaptation of plants to environmental conditions, and their quantity varies depending on the numerous ecological factors to which the plant is exposed [2,3], including temperature, humidity, light intensity, water supply, and minerals [4]. Phenolic compounds represent one of the three main groups of plant secondary metabolites [5]. Among these compounds, phenolics are particularly important due to their ability to eliminate free radicals and to function as antioxidants. Likewise, secondary metabolites are attributed with numerous protective functions in the human body, including antioxidative, antibiotic, anticarcinogenic, and pharmacological effects [6]. Health promoting effects of plant-derived secondary metabolites have been well documented [6-9]. 
The genus Inula L. (Asteraceae) includes species native to Europe, Africa, and Asia, and naturalized in America, among which Inula helenium, I. salicina, and I. britannica are best-known. Elecampane (I. helenium L.) is a perennial herbaceous plant in which oval and elongated leaves without petioles grow on moderately branched shoots. I. helenium primarily populates warm, damp, open, and calcareous habitats near river and stream banks in beech and conifer forests; however, due to wider application, the successful growth of I. helenium has been enabled on territories outside its initial area [10]. Traditionally, I. helenium is used in the treatment of arthritis, diabetes, rheumatism, pulmonary tuberculosis, and acute respiratory diseases [11]. Apart from the given therapeutic effects, detailed investigations in recent years showed that I. helenium possesses significant amounts of bioactive compounds such as inulin, sesquiterpene lactones [12,13], phenolic acids, flavonoids, and terpenoids [14] with antibacterial [7], antiparasitic, antioxidant [15,16], and anticancer activities [8].

The determination of spatial and temporal dynamics in the synthesis of secondary metabolites, together with their quantitative variability and activity, has scientific and practical significance and provides an increase of exploitation of plant material from their natural habitats. On this basis, the elementary and primary goal of the research is the evaluation of time-conditioned, interpopulation, and variability among the plant organs by applying analysis of the total concentration of phenolics, flavonoids, and antioxidant activity of the I. helenium extracts.

\section{Results}

The investigations of content of secondary metabolites and antioxidant activity of I. helenium was conducted using different plant parts (root, stem, leaves, and inflorescences) from two localities (named Locality 1 and Locality 2 ) and in different time periods from Locality 1 (1a and $1 \mathrm{~b}$ ).

\subsection{Concentration of Total Phenolic Compounds}

The total concentration of phenolic compounds obtained in the ethanol extracts of the plant organs of the I. helenium is illustrated in Table 1.

Table 1. Total phenolic content in the different parts of I. helenium (mg of gallic acid (GA)/g).

\begin{tabular}{cccccc}
\hline Locality & Root & Stem & Leaves & Inflorescence & $p$ \\
\hline Locality 1a & $71.24 \pm 0.49$ & $27.43 \pm 0.12$ & $69.02 \pm 0.51$ & $89.85 \pm 1.38$ & $\mathrm{a}$ \\
Locality 1b & $67.22 \pm 0.80$ & $26.35 \pm 0.25$ & $67.08 \pm 0.69$ & $88.60 \pm 1.27$ & $\mathrm{a}$ \\
Locality 2 & $44.40 \pm 1.18$ & $16.73 \pm 0.18$ & $49.61 \pm 1.04$ & $61.06 \pm 0.57$ & $\mathrm{~b}^{*}$ \\
\hline
\end{tabular}

Each value is the average of three analyses \pm standard deviation. $p$ is the significance obtained by the Mann-Whitney $\mathrm{U}$ test; different letters indicate significant differences between localities; the asterisk is for significant level $p<0.01$.

The total concentration of phenolic compounds in the plant extracts obtained from the organs of $I$. helenium varied from 16.73 to $89.85 \mathrm{mg}$ of gallic acid (GA)/g. Regarding the plant parts, the greatest quantity of phenolics was measured in the extracts obtained from inflorescences ( $89.85 \mathrm{mg}$ of GA/g), whereas the concentration of phenolic compounds in roots and leaves were similar. The lowest quantity of phenolics was observed in the stem extracts. While analyzing the values obtained from the samples collected from the same locality but in different time periods, it was detected that the values of the total concentration of phenolic compounds slightly decreased. Additionally, the values of the samples taken from Locality 2 were the lowest.

\subsection{Concentration of Flavonoids}

The flavonoid concentration of I. helenium extracts is shown in Table 2. 
Table 2. Flavonoid content in the different parts of I. helenium (mg of rutin ( $\mathrm{Ru}) / \mathrm{g}$ ).

\begin{tabular}{cccccc}
\hline Locality & Root & Stem & Leaves & Inflorescence & $\boldsymbol{p}$ \\
\hline Locality 1a & $20.27 \pm 0.29$ & $66.88 \pm 0.39$ & $376.22 \pm 2.88$ & $41.47 \pm 1.61$ & $\mathrm{a}$ \\
Locality 1b & $12.56 \pm 0.19$ & $29.01 \pm 0.37$ & $250.86 \pm 3.35$ & $38.23 \pm 0.33$ & $\mathrm{ab}$ \\
Locality 2 & $9.32 \pm 0.21$ & $20.04 \pm 0.61$ & $191.20 \pm 1.25$ & $25.42 \pm 0.56$ & $\mathrm{~b}$ \\
\hline
\end{tabular}

Each value is the average of three analyses \pm standard deviation. $p$ is the significance obtained by the Mann-Whitney $\mathrm{U}$ test; different letters indicate significant differences between localities $(p<0.05)$.

The quantity ranges between 9.32 and $376.22 \mathrm{mg}$ of rutin $(\mathrm{Ru}) / \mathrm{g}$ of the extracts with the highest flavonoid concentration measured in the ethanol extract of leaves, whereas the values of flavonoids were lower in the roots. While observing the values of the samples taken from the same locality but in different time period, it was noticed that the values of the total concentration of flavonoids greatly decreased. In addition, the values obtained from the second locality followed the trend of low values. In both cases, the same trend was observed, since the highest concentration of flavonoids was observed in the leaf extracts and the lowest in extracts obtained from roots.

\subsection{Antioxidant Activity}

The results of antioxidant activity of plant parts extracts from I. helenium are illustrated in Table 3.

Table 3. Antioxidant activity of the different parts of I. helenium $\left(\mathrm{IC}_{50}, \mu \mathrm{g} / \mathrm{ml}\right)$.

\begin{tabular}{cccccc}
\hline Locality & Root & Stem & Leaves & Inflorescence & $p$ \\
\hline Locality 1a & $161.60 \pm 2.11$ & $619.73 \pm 3.05$ & $338.83 \pm 2.95$ & $183.95 \pm 1.51$ & $\mathrm{a}$ \\
Locality 1b & $198.01 \pm 1.84$ & $842.05 \pm 4.16$ & $573.82 \pm 3.12$ & $222.25 \pm 1.92$ & $\mathrm{a}$ \\
Locality 2 & $285.10 \pm 2.35$ & $1563.02 \pm 6.77$ & $865.32 \pm 4.88$ & $427.35 \pm 2.08$ & $\mathrm{~b}^{*}$ \\
\hline
\end{tabular}

Each value is the average of three analyses \pm standard deviation. $p$ is the significance obtained by the Mann-Whitney $\mathrm{U}$ test; different letters indicate significant differences between localities; the asterisk is for significant level $p<0.01$.

The antioxidant activity of the plant organs of the I. helenium varied from 161.60 to $1563.02 \mu \mathrm{g} / \mathrm{ml}$ of the extract. Among the different plant parts, root samples demonstrated the largest capacity to neutralize DPPH radicals. Significant antioxidant activity was also noticed in the case of the inflorescence extract from Locality $1 \mathrm{a}\left(\mathrm{IC}_{50}=183.95 \mu \mathrm{g} / \mathrm{ml}\right)$. The stem extracts showed the lowest capacity to neutralize free radicals. In addition to the plant parts, sampling time, together with locality, influenced the capacity of I. helenium extracts to neutralize free radicals, since the highest antioxidant activity was measured in extracts from roots sampled from Locality 1a, while antioxidant capacity decreased in samples from Locality $1 \mathrm{~b}$ and Locality 2.

\subsection{Correlation Coefficient}

The results of the degree of correlation between plant parts, localities, and type of analysis are presented in Table 4.

Based on the results presented in Table 4, it was shown that there was a significant correlation between the investigated parameters. The values of correlation between the examined compounds and the antioxidant activity for localities showed that there was a significant correlation between the quantity of phenolic compounds and antioxidant activity for all localities, while no significant correlation was shown between total flavonoids and antioxidant activity. 
Table 4. Correlation coefficient (r) between the quantity of TP (total phenolic compounds), TF (total flavonoids), and AA (antioxidant activity) comparing plant parts and localities.

\begin{tabular}{|c|c|c|c|c|}
\hline \multicolumn{5}{|c|}{ Plant Parts } \\
\hline \multirow{4}{*}{ Root } & & $\mathrm{TP}$ & $\mathrm{TF}$ & $\mathrm{AA}$ \\
\hline & $\mathrm{TP}$ & 1 & 0.816 & -0.988 \\
\hline & $\mathrm{TF}$ & - & 1 & -0.894 \\
\hline & $\mathrm{AA}$ & - & - & 1 \\
\hline \multirow[t]{3}{*}{ Stem } & $\mathrm{TP}$ & 1 & 0.715 & -0.990 \\
\hline & $\mathrm{TF}$ & - & 1 & -0.803 \\
\hline & $\mathrm{AA}$ & - & - & 1 \\
\hline \multirow[t]{3}{*}{ Leaves } & $\mathrm{TP}$ & 1 & 0.805 & -0.932 \\
\hline & $\mathrm{TF}$ & - & 1 & -0.965 \\
\hline & $\mathrm{AA}$ & - & - & 1 \\
\hline \multirow[t]{3}{*}{ Inflorescence } & $\mathrm{TP}$ & 1 & 0.988 & -0.994 \\
\hline & $\mathrm{TF}$ & - & 1 & -0.998 \\
\hline & AA & - & & 1 \\
\hline \multicolumn{5}{|c|}{ Localities } \\
\hline \multirow{4}{*}{ Locality 1a } & & $\mathrm{TP}$ & $\mathrm{TF}$ & $\mathrm{AA}$ \\
\hline & $\mathrm{TP}$ & 1 & 0.035 & -0.931 \\
\hline & $\mathrm{TF}$ & - & 1 & 0.143 \\
\hline & AA & - & - & 1 \\
\hline \multirow[t]{3}{*}{ Locality $1 \mathrm{~b}$} & $\mathrm{TP}$ & 1 & 0.138 & -0.863 \\
\hline & $\mathrm{TF}$ & - & 1 & 0.265 \\
\hline & $\mathrm{AA}$ & - & - & 1 \\
\hline \multirow[t]{3}{*}{ Locality 2} & $\mathrm{TP}$ & 1 & 0.249 & -0.834 \\
\hline & $\mathrm{TF}$ & - & 1 & 0.114 \\
\hline & $\mathrm{AA}$ & - & - & 1 \\
\hline
\end{tabular}

\section{Discussion}

Phenolic compounds are highly soluble in polar solvents [17] and among them, ethanol is one of the most effective solvents for polyphenolic compounds and it is safe for human use [18,19].

The primary role of plant secondary metabolism is adaptation to different ecological factors, and products of secondary metabolism are conditioned by plant primary metabolism [20]. Locality 1 is a mesophilous habitat, i.e., a meadow located at an altitude of $973 \mathrm{~m}$. Locality 2 is a hygrophilous habitat, i.e., the edge of the forest in the vicinity of the stream located at an altitude of $447 \mathrm{~m}$. The analysis of the content of secondary metabolites among the sampled populations growing at different altitudes showed significant difference between populations in the quantity of the investigated metabolites. The plant species in the habitats with the increased intensity of light contain higher content of phenolics since these metabolites have considerable influence on the adaptational abilities of plants populating these habitats and, therefore, the quantity of phenolics in a certain species increases proportionally with the higher altitudes. The increased quantity of phenolic compounds in plants plays a protective role against UV-b rays, which are more intense at higher altitudes [21,22]. Numerous studies have confirmed that plants produce larger quantities of secondary metabolites in order to protect protein photosystem II and DNA from harmful UV radiation [23]. It has been demonstrated that the more intense exposure of the species Catharanthus roseus to UV-b radiation brings about greater production of certain secondary metabolites, such as vincristine and vinblastine [24].

It was noticed that there were certain differences in the total concentration of phenolic compounds in the plant parts of I. helenium with the highest concentrations of phenolics observed in the flower extract ( $89.85 \mathrm{mg}$ of GA/g). Similar results were obtained by analyzing the species Euphorbia helioscopia L., where the highest concentration of phenolic compounds was in the flower extract [25]. The authors who performed the comprehensive analysis of qualitative-quantitative composition of plant organs showed the difference in values of these compounds in flowers, leaves, stem, and root. The concentration 
of phenolic compounds in a particular plant organ depends upon the phenolic synthesis in those organs. The variation in the quantity of these compounds relies on the difference in morphological and anatomical structures, as well as in the numerous physiological processes that occur in different plant organs [26].

Further observations of our study revealed the difference in the total concentration of the phenolic compounds based on the time of the sampling. The samples from the Locality 1, sampled in July, had greater quantities of phenolics in comparison with samples from the same locality but sampled in October. The climatic differences in the given period may speed up or slow down the process of accumulation of phenolics in plants and their organs. The difference in seasonal variability of the concentration of phenolic compounds of a certain species depends upon the length of day and the differences in day and night temperatures [27]. Phenological changes are mostly influenced by differences between spring and summer temperatures [28]. This fact is highly relevant in terms of plant metabolism and synthesis of phenolic compounds.

In addition to total phenolics, the results also revealed the difference in the concentration of flavonoids since the quantity of flavonoids increased with an increase in altitude. As has been shown, the influence of UV-b rays increases the production of flavonoids in barley [29].

The leaves of the I. helenium contained the greatest amounts of flavonoids (376.22 $\mathrm{mg} \mathrm{of} \mathrm{Ru/g}$ ). Flavonoids belong to the largest group of phenolic compounds and can be found in all plant parts, particularly in the cells of the photosynthetic apparatus and accordingly, in leaves [9]. The fact that the leaf extracts contained the highest concentration of flavonoids is in accordance with numerous studies [30,31]. The research demonstrated that the species that grew in a mesophilous habitat produced a greater quantity of flavonoids in comparison with the species in a hygrophilous habitat. Likewise, Ranunculus acris growing in semi dry habitats had greater leaf area than those in a wet habitat [32].

The quantity of flavonoid variation is greatly influenced by the time of sampling of I. helenium. The species collected in Locality 1 in July contained higher concentrations of flavonoids in comparison with the samples taken in October. Previous studies on Salvia fruticosa Mill. and Rosmarinus officinalis L. demonstrated that the difference in the quantity of flavonoids greatly depends upon the group of ecological factors and the impact they have in a certain habitat [33].

The results for antioxidant activity of the extracts from the I. helenium established the differences between the populations sampled at different altitudes. The plant population sampled from Locality 1 (at an altitude of $973 \mathrm{~m}$ ) showed greater antioxidant activity in all plant parts in comparison to the plant population sampled from Locality 2 (at an altitude of $447 \mathrm{~m}$ ). These results are in accordance with the studies that pointed out that the samples collected at higher altitudes had better antioxidant activity than the extracts of the samples taken at lower altitudes [22,34].

The highest value of antioxidant activity was observed in the root extract $(161.60 \mu \mathrm{g} / \mathrm{ml})$. Previous investigations demonstrated that the main phenolic compounds in the root extract are phenolic acids (caffeic, chlorogenic, dicaffeoyl quinic, hydroxibenzoic); terpenes (alantolactone); and different flavonoids (epicatechin, catechin gallate, ferulic acid-4-O-glucoside, dihydroquercetin pentosyl rutinoside, kaempherol-7-O-dipentoside, quercetin-3-O- $\beta$-glucopyranoside) [16,35], among which the root extract of the I. helenium contains the most substantial quantity of caffeic acid [16]. Bearing in mind that these phenolic acids show high antioxidant values due to the interruption of the reaction of oxidation, the DPPH scavenging capacity of extracts may be predominantly due to their phenolic hydroxyl groups.

The relations among the content of secondary metabolites and antioxidant activity have already been established for several plant species [36,37]. To further instantiate the correlation, plant parts of different Teucrium species $[38,39]$ showed significant linear correlation between the concentration of phenols and antioxidant activity. The correlation between the total phenolic content and antioxidant activity in the extracts of plant parts have negative value since the increase in the quantity of the analyzed compounds was accompanied by the decrease of the antioxidant activity. In other words, the lower the $\mathrm{IC}_{50}$ values are, the greater the antioxidant efficiency is. The obtained values for 
the correlation between the quantity and the antioxidant activity of phenolic compounds suggest that the phenolic compounds are the principal active substances and the bearers of the antioxidant activity. Therefore, the phenolic content of plants may contribute directly to the antioxidant activity of extracts [37].

Seasonal variations in the amount of flavonoids are demonstrated by Alías et al. [40]. According to these authors, the concentration of flavonoids is conditioned by climate characteristics (particularly temperature), which indicates the ecological functions of these metabolites. The time-space variability in the production of secondary metabolites could affect the ecological interactions of the species and their ecophysiological behavior, which varies depending on the season and the plant organ [41]. Interpopulation variations have advantage since the species will be more likely to survive changes with the adequate amount of compounds to respond to adverse environments [42].

\section{Materials and Methods}

\subsection{Plant Material}

The plant material was sampled from different localities in Western Serbia (Table 5). Locality $1 \mathrm{a}$ was the same locality as Locality $1 \mathrm{~b}$ with the only difference being the samples were taken in different time periods. The localities from which the species were sampled were $40 \mathrm{~km}$ apart from each other, and these localities differed in the type of habitat and the group of ecological factors predominant in the habitats. Under these environmental conditions, the flowering period of I. helenium is from the beginning of June to the end of October. The voucher specimen of I. helenium was deposited in the Herbarium at the Department of Biology and Ecology, Faculty of Science, University of Kragujevac. Collection of plant material was carried out by sampling flowering branches from several representative individuals of the population. The plant material was air-dried in a dark place and at ambient temperature. The dried material was powdered and stored in sealed containers until use.

Table 5. General sampling data of I. helenium.

\begin{tabular}{|c|c|c|c|c|c|}
\hline Sample & Locality & $\begin{array}{c}\text { Type of } \\
\text { Habitat/Vegetation }\end{array}$ & $\begin{array}{l}\text { Altitude and } \\
\text { Exposure }\end{array}$ & $\begin{array}{l}\text { Latitude and } \\
\text { Longitude }\end{array}$ & $\begin{array}{c}\text { Date of } \\
\text { Sampling }\end{array}$ \\
\hline Sample 1 & $\begin{array}{l}\text { Locality 1a } \\
\text { (Bratljevo) }\end{array}$ & $\begin{array}{l}\text { Mesophilous habitat, } \\
\text { the edge of the forest }\end{array}$ & $973 \mathrm{~m}, \mathrm{~W}$ & $\begin{array}{l}43^{\circ} 28^{\prime} 32^{\prime \prime} \mathrm{N} \\
20^{\circ} 10^{\prime} 24^{\prime \prime} \mathrm{S}\end{array}$ & 12 July 2014 \\
\hline Sample 2 & $\begin{array}{l}\text { Locality } 1 b \\
\text { (Bratljevo) }\end{array}$ & $\begin{array}{l}\text { Mesophilous habitat, } \\
\text { the edge of the forest }\end{array}$ & $973 \mathrm{~m}, \mathrm{~W}$ & $\begin{array}{l}43^{\circ} 28^{\prime} 32^{\prime \prime} \mathrm{N} \\
20^{\circ} 10^{\prime} 24^{\prime \prime} \mathrm{S}\end{array}$ & 19 October 2014 \\
\hline Sample 3 & $\begin{array}{l}\text { Locality } 2 \\
\text { (Prilike) }\end{array}$ & $\begin{array}{l}\text { Hygrophilous habitat, } \\
\text { forest stream bank }\end{array}$ & $447 \mathrm{~m}, \mathrm{~W}$ & $\begin{array}{l}43^{\circ} 37^{\prime} 50^{\prime \prime} \mathrm{N} \\
20^{\circ} 8^{\prime} 44^{\prime \prime} \mathrm{S}\end{array}$ & 12 July 2014 \\
\hline
\end{tabular}

\subsection{Preparation of Plant Extracts}

One gram was measured from every sample of the ground plant material. The plant material was transferred to an Erlenmeyer flask into which $30 \mathrm{~mL}$ of ethanol was added. Previous research established ethanol as a prominent solvent of the extraction of bioactive compounds from I. helenium [43,44]. The extraction was performed using a Soxhlet apparatus. The obtained extract was preserved in a cold and dark place.

\subsection{Determination of Total Phenolics in the Plant Extracts}

The total phenolic concentration was determined using gallic acid as a standard [45]. The reaction mixture $\left(0.5 \mathrm{~mL}\right.$ of the plant extract, $2 \mathrm{~mL}$ of $7.5 \% \mathrm{NaHCO}_{3}$, and $2.5 \mathrm{~mL}$ of $10 \%$ Folin-Ciocalteu reagent) was incubated at $45^{\circ} \mathrm{C}$ for $45 \mathrm{~min}$ and the absorbance was measured at $765 \mathrm{~nm}$. The total phenolic content was expressed in terms of gallic acid equivalent (mg of GA/g of extract). 


\subsection{Determination of Total Flavonoids in the Plant Extracts}

The concentration of flavonoids was determined using rutin as a standard [46]. The test sample contained $1 \mathrm{ml}$ of the extract solution and $1 \mathrm{ml}$ of $2 \% \mathrm{AlCl}_{3}$. The samples were incubated at $20{ }^{\circ} \mathrm{C}$ for $60 \mathrm{~min}$ and the absorbance was measured at $415 \mathrm{~nm}$. The concentration of flavonoids was expressed in terms of rutin equivalent ( $\mathrm{mg}$ of $\mathrm{Ru} / \mathrm{g}$ of extract).

\subsection{Evaluation of Antioxidant Activity}

The efficiency of the plant extract to scavenge 1,1-diphenyl-2-picrylhydrazyl (DPPH) free radicals was evaluated using the spectrophotometric method [47], accepted with adequate modifications [39]. The $\mathrm{IC}_{50}$ values were estimated through the non-linear regression analysis using the \% inhibition versus the concentration sigmoidal curve. In presented results, antioxidant efficiency of the extracts increased with the decreasing of $\mathrm{IC}_{50}$ values.

\subsection{Statistical Analysis}

Statistical analysis was performed using the SPSS (Chicago, IL) statistical software package (SPSS for Windows, version XII, 2008). Data are expressed as arithmetic mean of three analyses \pm standard deviation. Comparisons were done using the Mann-Whitney U test ( $p<0.05$ or 0.01 ). Correlation coefficient (r) was used to study the relationship between variables.

\section{Conclusions}

The results of this research demonstrate that there is a significant variation in the quantity of secondary metabolites of I. helenium, which was sampled in different populations, among different plant organs, and in different time periods. The research provides evidence that the plant organs of the I. helenium are rich in phenolic compounds and that the greatest concentration of phenolic compounds was found in inflorescences. The highest concentration of flavonoids was observed in leaves, whereas the most expressive antioxidant activity was detected in the root and inflorescence. In addition, the concentrations of secondary metabolites in I. helenium depend on the time period of sampling. The increased quantity and activity of phenolic compounds in the samples of plant populations from the high-altitude locality prove the claim that phenolics are vital in terms of ecophysiological adaptation of the species I. helenium to the specific ecological conditions predominant in the habitats from which the samples were collected. Obtained results show a significant role for the exploitation of plant material sampled from natural or cultivated habitats.

Author Contributions: N.Z. partly conducted field work, organized and performed experiments, planned the effective presentation of data, and wrote the paper; D.J. participated in the writing of the manuscript and revised the paper in accordance with the instructions; M.S. proposed the theme, partly conducted the field work, and provided guidance and supervision to organize the experiments and analyze the data.

Funding: This investigation was supported by the Ministry of Science and Technological Development of the Republic of Serbia III41010.

Conflicts of Interest: The authors declare no conflict of interest.

\section{References}

1. Bourgaud, F.; Gravot, A.; Milesi, S.; Gontier, E. Production of plant secondary metabolites: A historical perspective. Plant Sci. 2001, 161, 839-851. [CrossRef]

2. Jakovljević, D.; Stanković, M.; Bojović, B.; Topuzović, M. Regulation of early growth and antioxidant defense mechanism of sweet basil seedlings in response to nutrition. Acta Physiol. Plant. 2017, 39, 243. [CrossRef]

3. Oh, M.M.; Trick, H.N.; Rajasheka, C.B. Secondary metabolism and antioxidants are involved in environmental adaptation and stress tolerance in lettuce. J. Plant Physiol. 2009, 166, 180-191. [CrossRef] [PubMed]

4. Ramakrishna, A.; Ravishankar, G.A. Influence of abiotic stress signals on secondary metabolites in plants. Plant Signal. Behav. 2011, 6, 1720-1731. [PubMed] 
5. Larbat, R.; Paris, C.; Le Bot, J.; Adamowicz, S. Phenolic characterization and variability in leaves, stems and roots of Micro-Tom and patio tomatoes, in response to nitrogen limitation. Plant Sci. 2014, 224, 62-73. [CrossRef] [PubMed]

6. Khan, F.; Niaz, K.; Maqbool, F.; Ismail Hassan, F.; Abdollahi, M.; Nagulapalli Venkata, K.C.; Nabavi, S.M.; Bishayee, A. Molecular targets underlying the anticancer effects of quercetin: An update. Nutrients 2016, 8, 529. [CrossRef] [PubMed]

7. Deriu, A.; Zanetti, S.; Sechi, L.A.; Marongiu, B.; Piras, A.; Porcedda, S.; Tuveri, E. Antimicrobial activity of Inula helenium L. essential oil against Gram-positive and Gram-negative bacteria and Candida spp. Int. J. Antimicrob. Agents 2008, 31, 588-590. [CrossRef] [PubMed]

8. Li, Y.; Ni, Z.Y.; Zhu, M.C.; Dong, M.; Wang, S.M.; Shi, Q.W.; Zhang, M.L.; Wang, Y.F.; Huo, C.H.; Kjyota, H.; et al. Antitumour activities of sesquiterpene lactones from Inula helenium and Inula japonica. Z. Naturfrosch. C 2012, 67, 375-380. [CrossRef]

9. Kumar, S.; Pandey, A.K. Chemistry and biological activities of flavonoids: An overview. Sci. World J. 2013, 2013, 16. [CrossRef]

10. Filipović, V.; Jevdjović, R.; Glamočlija, D.; Jovanović, B. Possibility of growing elecampane in conditions of non-watering field crop production. J. Agric. Sci. 2005, 50, 1-8. [CrossRef]

11. Mamedov, N.; Mehdiyeva, N.P.; Craker, E.L. Medicinal plants used in traditional medicine of the Caucasus and North America. J. Med. Act. Plants 2015, 4, 42-66.

12. Zhao, T.M.; Zhang, M.L.; Shi, Q.U.; Kiyota, H. Chemical constituents of plants from the genus Inula. Chem. Biodiv. 2006, 3, 371-384. [CrossRef] [PubMed]

13. Wang, J.; Zhao, M.Y.; Guo, Y.C.; Zhang, M.S.; Liu, L.C.; Zhang, D.S.; Bai, X.M. Ultrasound-assisted extraction of total flavonoids from Inula helenium. Pharmacogn. Mag. 2012, 8, 166-170.

14. Afemei, M.; Gille, E.; Boz, I.; Toma, C.; Zamfirache, M.M. Aspects regarding the qualitative and quantitative phytochemical analysis of the Inula helenium L. species. Biologie vegetală 2012, 58, 29-34.

15. Wojdyło, A.; Oszmiański, J.; Czemerys, R. Antioxidant activity and phenolic compounds in 32 selected herbs. Food Chem. 2007, 105, 940-949. [CrossRef]

16. Spiridon, I.; Nechita, B.C.; Niculaua, M.; Silion, M.; Armatu, A.; Teaca, C.A.; Bodirlau, R. Antioxidant and chemical properties of Inula helenium root extracts. Cent. Eur. J. Chem. 2013, 11, 1699-1709. [CrossRef]

17. Zhou, K.; Yu, L. Effects of extraction solvent on wheat bran antioxidant activity estimation. LWT Food Sci. Technol. 2004, 37, 717-721. [CrossRef]

18. Shi, J.; Nawaz, H.; Pohorly, J.; Mittal, G.; Kakuda, Y.; Jiang, Y. Extraction of polyphenolics from plant material for functional foods-engeneering and technology. Food Rev. Int. 2005, 21, 139-166. [CrossRef]

19. Naidoo, Y.; Sadashiva, T.C.; Raghu, K. Antibacterial, antioxidant and phytochemical properties of the ethanolic extract of Ocimum obovatum E.Mey ex Benth. Indian J. Tradit. Knowl. 2016, 15, 57-61.

20. Kliebenstein, D.J.; Osbourn, A. Making new molecules-evolution of pathways for novel metabolites in plants. Curr. Opin. Plant Biol. 2012, 15, 415-423. [CrossRef]

21. Alonso-Amelot, M.E.; Oliveros-Bastidas, A.; Calcagno-Pisarelli, M.P. Phenolics and condensed tannins in relation to altitude in neotropical Pteridium spp. A field study in the Venezuelan Andes. Biochem. Syst. Ecol. 2004, 32, 969-981. [CrossRef]

22. Li, Y.; Gao, J.; Zhang, L.; Su, Z. Responses to UV-B exposure by saplings of the relict species Davidia involucrata Bill are modified by soil nitrogen availability. Pol. J. Ecol. 2014, 62, 101-110. [CrossRef]

23. Alonso-Amelot, M.E.; Oliveros-Bastidas, A.; Calcagno-Pisarelli, M.P. Phenolics and condensed tannins of high altitude Pteridium arachnoideum in relation to sunlight exposure, elevation, and rain regime. Biochem. Syst. Ecol. 2007, 35, 1-10. [CrossRef]

24. Binder, B.Y.; Peebles, C.A.; Shanks, J.V.; San, K.Y. The effects of UV-B stress on the production of terpenoid indole alkaloids in Catharanthus roseus hairy roots. Biotechnol. Prog. 2011, 25, 861-865. [CrossRef] [PubMed]

25. Maoulainine, L.B.M.; Jelassi, A.; Hassen, I.; Boukhari, A.O.M.S.O. Antioxidant properties of methanolic and ethanolic extracts of Euphorbia helioscopia L. aerial parts. Int. Food Res. J. 2012, 19, 1125-1130.

26. Bystricka, J.; Vollmannova, A.; Margitanova, E.; Cicova, I. Dynamics of polyphenolics formation in different plant parts and different growth phases of selected buckwheat cultivars. Acta Agric. Slov. 2010, 95, 225-229. [CrossRef] 
27. Erturk, Y.; Ercisli, S.; Şengül, M.; Eser, Z.; Haznedear, A.; Turan, M. Seasonal variation of total phenolic, antioxidant activity and minerals in fresh tea shoots (Camellia sinensis var. sinensis). Pak. J. Pharm. Sci. 2010, 23, 69-74.

28. Jabłońska, K.; Kwiatkowska-Falińska, A.; Czernecki, B.; Walawender, P.J. Changes in spring and summer phenology in Poland-responses of selected plant species to air temperature variations. Pol. J. Ecol. 2015, 63, 311-319. [CrossRef]

29. Liu, L.; Gitz, C.D.; McClure, W.J. Effects of UV-B on flavonoids, ferulic acid, growth and photosynthesis in barley primary leaves. Physiol. Plant 1995, 93, 725-733. [CrossRef]

30. Barros, L.; Carvalho, A.M.; Ferreira, C.F.R. Comparing the composition and bioactivity of Crataegus monogyna flowers and fruits used in folk medicine. Phytochem. Anal. 2011, 22, 181-188. [CrossRef]

31. Riahi, L.; Chograni, H.; Elferchichi, M.; Zaouali, Y.; Zoghlami, N.; Mliki, A. Variations in Tunisian wormwood essential oil profiles and phenolic contents between leaves and flowers and their effects on antioxidant activities. Ind. Crop. Prod. 2013, 46, 290-296. [CrossRef]

32. Kołodziejek, J.; Michlewska, S. Effect of soil moisture on morpho-anatomical leaf traits of Ranunculus acris (Ranunculaceae). Pol. J. Ecol. 2015, 63, 400-413. [CrossRef]

33. Papageorgiou, V.; Gardeli, C.; Mallouchos, A.; Papaioannou, M.; Komaitis, M. Variation of the chemical profile and antioxidant behavior of Rosmarinus officinalis L. and Salvia fruticosa Miller grown in Greece. J. Agric. Food Chem. 2008, 56, 7254-7264. [CrossRef]

34. Ganzera, M.; Guggenberger, M.; Stuppner, H.; Zidorn, C. Altitudinal variation of secondary metabolite profiles in flowering heads of Matricaria chamomilla cv. BONA. Planta Med. 2008, 74, 453-457. [CrossRef] [PubMed]

35. Talib, H.W.; Mahasneh, M.A. Antiproliferative activity of plant extracts used against cancer in traditional medicine. Sci. Pharm. 2018, 78, 33-45. [CrossRef] [PubMed]

36. Ksouri, R.; Megdiche, W.; Falleh, H.; Trabelsi, N.; Boulaaba, M.; Smaoui, A.; Abdelly, C. Influence of biological, environmental and technical factors on phenolic content and antioxidant activities of Tunisian halophytes. C. R. Biol. 2008, 331, 865-873. [CrossRef]

37. Tosun, M.; Ercisli, S.; Sengul, M.; Ozer, H.; Polat, T. Antioxidant properties and total phenolic content of eight Salvia species from Turkey. Biol. Res. 2009, 42, 175-181. [CrossRef]

38. Stanković, M.S.; Topuzović, M.; Solujić, S.; Mihailović, V. Antioxidant activity and concentration of phenols and flavonoids in the whole plant and plant parts of Teucrium chamaedrys L. var. glanduliferum Haussk. J. Med. Plants Res. 2010, 4, 2092-2098.

39. Stanković, M.S.; Nićiforović, N.; Topuzović, M.; Solujić, S. Total phenolic content, flavonoid concentrations and antioxidant activity, of the whole plant and plant parts extracts from Teucrium montanum L. var. montanum, f. supinum (L.) Reichenb. Biotechnol. Biotechnol. Equip. 2011, 25, 2222-2227. [CrossRef]

40. Alías, J.C.; Sosa, T.; Valares, C.; Escudero, J.C.; Chaves, N. Seasonal variation of Cistus ladanifer L. diterpenes. Plants 2012, 1, 6-15. [CrossRef]

41. Valares Masa, C.; Sosa Díaz, T.; Alías Gallego, J.C.; Chaves Lobón, N. Quantitative Variation of Flavonoids and Diterpenes in Leaves and Stems of Cistus ladanifer L. at Different Ages. Molecules 2016, 21, 275. [CrossRef] [PubMed]

42. Valares Masa, C.; Alías Gallego, J.C.; Chaves Lobón, N.; Sosa Díaz, T. Intra-Population Variation of Secondary Metabolites in Cistus ladanifer L. Molecules 2016, 21, 945. [CrossRef] [PubMed]

43. Petkova, N.; Ivanov, I.; Vrancheva, R.; Denev, P.; Pavlov, A. Ultrasound and microwave-assisted extraction of elecampane (Inula helenium) roots. Nat. Prod. Commun. 2017, 12, 171-174. [CrossRef] [PubMed]

44. Park, E.J.; Kim, Y.M.; Park, S.W.; Kim, H.J.; Lee, J.H.; Lee, D.U.; Chang, K.C. Induction of HO-1 through p38 MAPK/Nrf2 signaling pathway by ethanol extract of Inula helenium L. reduces inflammation in LPS-activated RAW 264.7 cells and CLP-induced septic mice. Food Chem. Toxicol. 2013, 55, 386-395. [CrossRef] [PubMed]

45. Singleton, V.L.; Orthofer, R.; Lamuela, R.R.M. Analysis of total phenols and other oxidation substrates and antioxidants by means of Folin-Ciocalteu reagent. Methods Enzymol. 1991, 299, 152-178. 
46. Quettier, D.C.; Gressier, B.; Vasseur, J.; Dine, T.; Brunet, C.; Luyckx, M.; Cazin, M.; Cazin, J.C.; Bailleul, F.; Trotin, F. Phenolic compounds and antioxidant activities of buckwheat (Fagopyrum esculentum Moench) hulls and flour. J. Ethnopharmacol. 2000, 72, 35-42. [CrossRef]

47. Takao, T.; Watanabe, N.; Yagi, I.; Sakata, K. A simple screeninig method for antioxidant and isolation of several antioxidants produced by marine bacteria from fish and shellfish. Biosci. Biotechnol. Biochem. 1994, 58, 1780-1783. [CrossRef] 